\title{
Ventilatory Management of COVID-19-related ARDS: Stick to Basics and Infection Control
}

\author{
Rajesh Chawla ${ }^{1}$, Prashant Nasa ${ }^{2}$ \\ Keywords: Acute respiratory distress syndrome, COVID-19, Ventilation. \\ Indian Journal of Critical Care Medicine (2020): 10.5005/jp-journals-10071-23513
}

The pandemic of coronavirus disease-2019 (COVID-19) has brought the field of critical care medicine into limelight as never before. In a large database from the United states (US), the need of intensive care unit (ICU) admission was in $2 \%$ of the confirmed patients with case fatality rate of $5 \%$. $^{1}$ The ICU mortality however, is $39 \%$ and $50-100 \%$ in patients requiring invasive mechanical ventilation. ${ }^{2,3}$ The pandemic of this nature obviously caused medical world frenzied with multitude of expert opinions, consensus statements, and guidelines on the management of critically ill COVID-19 patients in the last few months. Lungs are the primary target organ for severe acute respiratory syndrome coronavirus-2 (SARS-CoV-2), and the acute respiratory distress syndrome (ARDS) due to severe pneumonia is the most common cause of ICU admission.

In this issue of the journal, Maddani et al. conducted a multicentric survey among critical care physicians in India on ventilatory management of COVID-19-related ARDS (CARDS). ${ }^{4}$ The survey was conducted over 6 weeks in May-June 2020. The results showed few critical observations. The $32 \%$ of responders said that they would be using noninvasive respiratory support [high-fow nasal oxygen (HFNO), 19\%; noninvasive ventilation (NIV), 13\%] for the management of acute hypoxemic respiratory failure (AHRF) in case of failure to maintain oxygen saturation with face mask. The initial experiences on CARDS from China or the US showed higher mortality with invasive mechanical ventilation (IMV). ${ }^{5-7}$ There was also prolonged stay on ventilator (ranging from 10 to 17 days) and longer time to wean (causing shortage of ventilators during surge of patients). ${ }^{5-7}$ If IMV is associated with higher mortality, can we avoid intubation by using NIV, is a debate long ongoing. Conventionally, NIV is not recommended for moderate-to-severe ARDS. ${ }^{8}$ In case of AHRF due to H1N1 viral pneumonia, it was however tried in controlled ICU settings. ${ }^{8}$ In a recently published meta-analysis, NIV with helmet or HFNO were associated with reduced risk of intubation and mortality as compared to face mask alone in the management of AHRF. ${ }^{9}$ The preliminary reports of use of NIV or HFNC in COVID-19 are conflicting with high failure rate in moderate-to-severe ARDS. ${ }^{10-12}$ However, major regulatory bodies allowed the use of NIV or HFNC with limited evidence. ${ }^{13,14}$ The use of NIV may improve oxygenation in AHRF and temporarily reduce work of breathing but has no effect on natural disease progression, and may even delay in intubation and IMV in nonexpert hands. ${ }^{15,16}$ There is also a risk of further worsening of the lung injury, especially with higher tidal volumes generated spontaneously in case of inappropriate settings of NIV. ${ }^{16,17}$ In the LUNG-SAFE study, NIV use was associated with higher ICU mortality in patients with moderate-to-severe ARDS $\left(\mathrm{PaO}_{2} / \mathrm{FiO}_{2}<150 \mathrm{~mm} \mathrm{Hg}\right)^{18}$
${ }^{1}$ Department of Respiratory and Critical Care Medicine, Indraprastha Apollo Hospitals, Sarita Vihar, New Delhi, India

${ }^{2}$ Department of Critical Care Medicine, NMC Specialty Hospital, Dubai (UAE)

Corresponding Author: Rajesh Chawla, Department of Respiratory and Critical Care Medicine, Indraprastha Apollo Hospitals, Sarita Vihar, New Delhi, India, Phone: +91 9810033395, e-mail: drchawla@hotmail. com

How to cite this article: Chawla R, Nasa P. Ventilatory Management of COVID-19-related ARDS: Stick to Basics and Infection Control. Indian J Crit Care Med 2020;24(8):609-610.

Source of support: Nil

Conflict of interest: None

NIV and HFNC can be used at this time under controlled monitoring conditions for mild-to-moderate CARDS $\left(\mathrm{PaO}_{2} / \mathrm{FiO}_{2}>\right.$ $150 \mathrm{~mm} \mathrm{Hg}$ ) only. ${ }^{19}$ The positive response is usually evident soon after starting NIV or HFNC, and if there is no improvement in gas exchange, clinical condition, and/or worsening, patient should be intubated early. ${ }^{17,19}$

The aerosolization of the virus and the risk of nosocomial transmission to healthcare workers (HCWs) is other major concern associated with NIV and HFNC. The patient should thus be in the negative pressure isolation room which is not easily available, and the HCWs caring for the patients should be in complete personal protective equipment (PPE) appropriate for aerosol-generating procedures (AGPs). ${ }^{13,14}$

The CARDS has generated its own controversy with experts like Luciano Gattinoni opined that COVID-19 pulmonary pathology is not ARDS and proposed two phenotypes: $L$ and $H$ depending on the lung compliance (or elastance) and different ventilator strategies for each phenotype. ${ }^{20}$ The dichotomy of $\mathrm{L}$ and $\mathrm{H}$ phenotype is, however, not seen in large registries where median lung compliance reported was $26-28 \mathrm{~mL} / \mathrm{cm} \mathrm{H}_{2} \mathrm{O}$, typically close to compliance seen with other causes of ARDS. ${ }^{21,22}$ This does not, however, refute the possibility of different phenotypes in CARDS. The ARDS is an heterogeneous syndrome, and the subphenotypes based on clinical, biological, and physiological criteria are wellknown. ${ }^{23}$ These phenotypes can also respond differently to the conventional management of ARDS. ${ }^{23}$

Lung-protective ventilation for ARDS and its core strategy of tidal volume less than $6 \mathrm{~mL} / \mathrm{kg} /$ predicted body weight, plateau of pressure less than $30 \mathrm{~cm}$ of $\mathrm{H}_{2} \mathrm{O}$, and/or driving pressure less

(O) The Author(s). 2020 Open Access This article is distributed under the terms of the Creative Commons Attribution 4.0 International License (https://creativecommons. org/licenses/by-nc/4.0/), which permits unrestricted use, distribution, and non-commercial reproduction in any medium, provided you give appropriate credit to the original author(s) and the source, provide a link to the Creative Commons license, and indicate if changes were made. The Creative Commons Public Domain Dedication waiver (http://creativecommons.org/publicdomain/zero/1.0/) applies to the data made available in this article, unless otherwise stated. 
than $15 \mathrm{~cm}$ of $\mathrm{H}_{2} \mathrm{O}$ was shown to have mortality benefit for heterogeneous population of ARDS. The lung-protective ventilation should be observed in all patients of CARDS on IMV in the absence of any survival advantage with any other strategy. ${ }^{24}$

There was another significant observation seen in the study by Maddani et al., about the use of negative pressure isolation room for patients on IMV. ${ }^{4} 55 \%$ of responders from the medical college and $37 \%$ from corporate hospitals have opted for the practice of IMV without negative pressure isolation room. This difference in response was likely because of the availability of the resources, however, at the risk of compromising the safety of $\mathrm{HCWs}$. The IMV is usually associated with AGP procedures such as intubation, extubation, tracheal secretions open sampling of tracheal secretions, inadvertent endotracheal tube pilot balloon leak, tracheostomy, cardiopulmonary resuscitation, and emergency bag-mask ventilation. ${ }^{25}$ It is not practical to move intubated patient every time for an AGP to negative isolation room, especially in emergency.

In conclusion, the evidence about COVID-19 is evolving, and at present, the focus should be on the best supportive standard of care with compliance of infection control principles for the safety of patients and HCWs.

\section{References}

1. Stokes EK, Zambrano LD, Anderson KN, Marder EP, Raz KM, El Burai Felix S, et al. Coronavirus disease 2019 case surveillanceUnited States, January 22-May 30, 2020. Morb Mortal Wkly Rep 2020;69(24):759-765. DOI: 10.15585/mmwr.mm6924e2.

2. Abate SM, Ahmed Ali S, Mantfardo B, Basu B. Rate of intensive care unit admission and outcomes among patients with coronavirus: a systematic review and meta-analysis. PLoS One 2020;15(7):e0235653. DOI: 10.1371/journal.pone.0235653.

3. Almeshari MA, Alobaidi NY, Asmri MA, Alhuthail E, Alshehri Z, Alenezi $F$, et al. Mechanical ventilation utilization in COVID-19: a systematic review and meta-analysis. medRxiv 2020. DOI: 10.1101/2020.06.04.20122069.

4. Maddani SS, Deepa HC, Shwethapriya R, Chaudhari S. A multi-centre cross-sectional questionnaire-based study to know the practices and strategies of ventilatory management of COVID-19 patients among the treating physicians. Indian J Crit Care Med 2020;24(8):643-648.

5. Weiss $P$, Murdoch DR. Clinical course and mortality risk of severe COVID-19. Lancet 2020;395(10229):1014-1015. DOI: 10.1016/S01406736(20)30633-4

6. Richardson S, Hirsch JS, Narasimhan M, Crawford JM, McGinn T, Davidson KW, et al. Presenting characteristics, comorbidities, and outcomes among 5700 patients hospitalized with COVID-19 in the new york city area. J Am Med Assoc 2020;323(20):2052-2059. DOI: 10.1001/jama.2020.6775.

7. Yang X, Yu Y, Xu J, Shu H, Xia J, Liu H, et al. Clinical course and outcomes of critically ill patients with SARS-CoV-2 pneumonia in Wuhan, china: a single-centered, retrospective, observational study. Lancet Respir Med 2020;8(5):475-481. DOI: 10.1016/S2213-2600(20) 30079-5.

8. Chawla R, Dixit SB, Zirpe KG, Chaudhry D, Khilnani GC, Mehta Y, et al. ISCCM guidelines for the use of non-invasive ventilation in acute respiratory failure in adult ICUs. Indian J Crit Care Med 2020;24(Suppl 1):S61-S81. DOI: 10.5005/jp-journals-10071-G23186.

9. Ferreyro BL, Angriman F, Munshi L, Del Sorbo L, Ferguson ND, Rochwerg B, et al. Association of noninvasive oxygenation strategies with all-cause Mortality in adults with acute hypoxemic respiratory failure: a systematic review and meta-analysis. J Am Med Assoc 2020;324(1):1-12. DOI: 10.1001/jama.2020.9524.

10. Ñamendys-Silva SA. Respiratory support for patients with COVID-19 infection. Lancet Respir Med 2020;8(4):e18. DOI: 10.1016/S22132600(20)30110-7.

11. Wang K, Zhao W, Li J, Shu W, Duan J. The experience of high-flow nasal cannula in hospitalized patients with 2019 novel coronavirus-infected pneumonia in two hospitals of Chongqing, china. Ann Intensive Care 2020;10(1):37. DOI: 10.1186/s13613-020-00653-z.

12. Oranger M, Gonzalez-Bermejo J, Dacosta-Noble P, Llontop C, Guerder A, Trosini-Desert V, et al. Continuous positive airway pressure to avoid intubation in SARS-CoV-2 pneumonia: a two-period retrospective case-control study. Eur Respir J 2020;2001692. DOI: 10.1183/13993003.01692-2020.

13. NHS England. Guidance for the role and use of non-invasive respiratory support in adult patients with COVID19 (confirmed or suspected) 6 April 2020, Version 3. Available at: https://www.england. nhs.uk/coronavirus/wp-content/uploads/sites/52/2020/03/specialtyguide-NIV-respiratory-support-and-coronavirus-v3.pdf. (Accessed on July 29, 2020).

14. World Health Organization. Clinical management of severe acute respiratory infection (SARI) when COVID-19 disease is suspected. Updated 27th May 2020. https://www.who.int/publications/i/item/ clinical-management-of-covid-19 (Accessed on July 29, 2020).

15. Namendys-Silva SA, Hernández-Garay M, Rivero-Sigarroa E. Noninvasive ventilation for critically ill patients with pandemic H1N1 2009 influenza A virus infection. Crit Care 2010;14(2):407. DOI: 10.1186/ cc8883Epub 2010 Mar 17.

16. Carter C, Aedy H, Notter J. COVID-19 disease: non-invasive ventilation and high frequency nasal oxygenation. Clinics in Integrated Care 2020;1:100006. DOI: 10.1016/j.intcar.2020.100006.

17. Brochard L, Slutsky A, Pesenti A. Mechanical ventilation to minimize progression of lung injury in acute respiratory failure. Am J Respir Crit Care Med 2017;195(4):438-442. DOI: 10.1164/rccm.201605-1081CP.

18. Bellani G, Laffey JG, Pham T, Madotto F, Fan E, Brochard L, et al. Noninvasive ventilation of patients with ARDS: insights from the LUNG SAFE study. Am J Respir Crit Care Med 2017;195(1):67-77. DOI: 10.1164/ rccm.201606-13060C.

19. Shang Y, Pan C, Yang X, Zhong M, Shang X, Wu Z, et al. Management of critically ill patients with COVID-19 in ICU: statement from frontline intensive care experts in Wuhan, China. Version 2. Ann Intensive Care 2020;10(1):73. DOI: 10.1186/s13613-020-00689-1.

20. Marini JJ, Gattinoni L. Management of COVID-19 respiratory distress. J Am Med Assoc 2020. DOI: 10.1001/jama.2020.6825 [published online ahead of print, 2020 Apr 24].

21. Cummings MJ, Baldwin MR, Abrams D, et al. Epidemiology, clinical course, and outcomes of critically ill adults with COVID-19 in new york city: a prospective cohort study. Lancet 2020;395(10239):1763-1770. DOI: 10.1016/S0140-6736(20)31189-2.

22. Schenck EJ, Hoffman K, Goyal P, Choi J, Torres L, Rajwani K, et al. Respiratory mechanics and gas exchange in COVID-19 associated respiratory failure. Ann Am Thorac Soc 2020. DOI: 10.1513/ AnnalsATS.202005-427RL.

23. Wilson JG, Calfee CS. ARDS subphenotypes: understanding a heterogeneous syndrome. Crit Care 2020;24(1):102. DOI: 10.1186/ s13054-020-2778-x.

24. Fan E, Beitler JR, Brochard L, Calfee CS, Ferguson ND, Slutsky AS, et al. COVID-19-associated acute respiratory distress syndrome: is a different approach to management warranted? Lancet Respir Med 2020;8(8):816-821. DOI: 10.1016/S2213-2600(20)30304-0.

25. Tran K, Cimon K, Severn M, Pessoa-Silva CL, Conly J. Aerosol generating procedures and risk of transmission of acute respiratory infections to healthcare workers: a systematic review. PLoS One 2012;7(4):e35797. DOI: 10.1371/journal.pone.0035797. 